\title{
Improving the quality management system of goods and services based on the Blockchain concept implementation and quality assessment in the digital economy
}

\author{
Andrey Yakovlev ${ }^{1,}{ }^{*}$, Anna Chernikova $^{1}$, Maria Livintsova ${ }^{1}$, Tatiana Lebedeva ${ }^{1}$ \\ ${ }^{1}$ Peter the Great St. Petersburg Polytechnic University
}

\begin{abstract}
When studying the development of the modern consumer market in Russia, a large number of low-quality goods and services remains constant. All this is fixed, despite the significant amount of domestic and international standards of the market system of accreditation and certification of the production processes of goods and services that are used in our country. It casts doubt on the feasibility of using quality management systems in Russia based on ISO 9000 due to their low efficiency. This requires the creation of a more advanced quality management system and the introduction into everyday practice of an effective mechanism that excludes the possibility of low-quality goods and services appearing on the markets. Based on systematic analysis of the reviewed literature the paper shows that organizations are not interested in providing consumer goods with the required quality, and the costumer himself cannot get an objective view of the real quality of the goods or services offered to him. The paper shows the need to create equal information conditions for all market participants from producer to consumer to optimize quality management systems. In conditions of the transition to digital economy concepts, the economic practice proves the effectiveness of the "Distributed registry" technology application. The possibility of falsifying information is extremely difficult. It is the basis for solving the problem of reducing transaction costs and, as a consequence, the management mechanism formation within the quality management systems.
\end{abstract}

\section{Introduction}

Analysing the quality state of the modern consumer market in Russia, regretfully it should be noted that despite the large list of regulatory documents governing the requirements for goods and services, the presence of a market system of accreditation and certification of production processes recommended by international standards in the face of an increasing number of commercial organizations who have passed this procedure and got qualified confirmation of the fact of the company compliance to the recommendations of these standards, we have a vast number of counterfeit, falsified and simply poor-quality goods and services. Fig. 1 shows some data that give us an idea of the volume of their presence in the market.

* Corresponding author: yakovlev_aa@spbstu.ru 


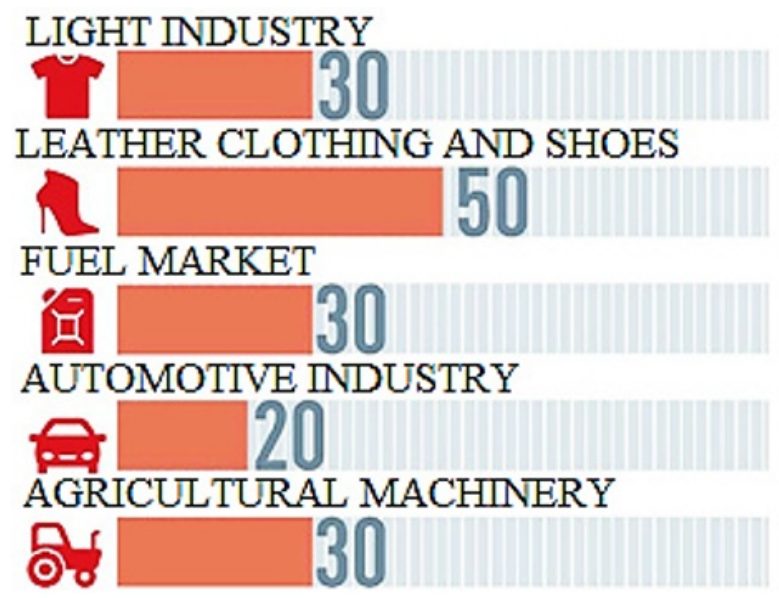

Source: Ministry of Industry and Trade of Russia and industry associations.

Fig. 1. The share of falsified goods and counterfeit in different markets in $\%$.

In the monetary and natural terms, it looks as follows.

1. The volume of illegal turnover of products (according to expert estimates):

- in the consumer market -2.5 trillion rubles, ( $9 \%$ of the total retail turnover);

$-15 \%$ of sales in the surveyed retail markets (food, alcohol, tobacco, light industry products, including sportswear, perfumes and cosmetics, feminine and child hygiene products, body care products, cleaning and detergents).

2. The volume of illegal fuel turnover in the whole country exceeds 10 million tons ( $30 \%$ of the total turnover).

Unauthorized selection of fuel from oil pipelines through illegal tapping and its processing at illegal oil-refineries into low-quality fuel is one of the main channels for illegal products entering the market.

On April 2019, the situation with the supply of low-quality oil products by Transneft, JSC to West European consumers was revealed. At the same time, all components of the supplier organization have been certified on the availability of quality management system (QMS) according to ISO 9001-2015. This brought substantial damage to the image of the Russian Federation as a whole and plus the claims from consumers of substandard petroleum productsworth more than $\$ 500$ million [1].

Unfortunately, the problem of prevention of falsification and counterfeiting is not a private problem in the Russian economy. Currently, it has outgrown the national borders and has become one of the most pressing problems of concern to governments of different countries and non-governmental organizations. Mostly, it concerns the consumers of lowquality goods and services, since their consumption involves a specific risk to consumers' lives, health and property.

Of course, the current situation cannot remain unanswered. The first reaction to it was the appearance of publications casting doubt on the feasibility of using QMS based on ISO 9000 in Russia due to their low efficiency. As well as the requirement was to develop a more advanced management system and to introduce an effective mechanism into everyday practice that excludes the possibility of low-quality goods and services appearing on the markets $[2-8]$.

\section{Methods}


As we all know, the practical management tasks are organizational tasks. The traditional method of their solving is based on the concept of a systems approach, on system analysis and cybernetic methodology.

From the perspective of cybernetics, management is the impact on the object aimed to achieve a certain goal. Therefore, when starting to solve a management problem, forming a management system, a researcher, first of all, must understand the goals and objectives of management.

The purpose of the functioning of any autonomous organization is to ensure the possibility of its existence by extracting energy from its environment [9].

Aristotle introduced the concept of energy. With the time on, we began to consider this concept as a physical phenomenon, while understanding under energy what provides the opportunity to do work.

The formation of an exchange and then a market economy, the money-laundering led to the emergence of a specific form, formally suitable for the definition of energy, a substrate called money, capable of providing the ability to perform work, especially in conditions when the possibility of direct access to the physical phenomenon of "energy" is excluded. Money is not inherently energy in the sense of formulated by A. Einstein formula of total energy of the substance: $E=m \cdot c^{2}$. However, in the modern economic space money provides an opportunity to force a person to do work becoming in this sense an analogue of energy as a kind of crypto-energy.

As a result, the goal of the existence of a commercial organization is to extract cryptoenergy $^{\dagger}$ (the production of money) by providing consumers with goods and services. These goods and services could not only offer consumers an implementation of functions in accordance with their intended use and the desired characteristics, but also are perceived by these consumers as a certain value and provide them with some kind of benefit [10].

In support of this contention, reference should be made to the well-known "universal formula of capital" of Karl Marx:

$\mathrm{M}-\mathrm{C}-\mathrm{M}$ (Money - Commodity - Money),

which expresses the process of circulation of any type of capital regardless of what sphere of the economy it is applied.

The expression (1) follows that the ultimate purpose and driving motive of the exchange process is not the use value but the exchange value. The cyclic exchange process is a sequence of conversion of free crypto-energy into the bound product energy followed by its transformation in the sale process again into free crypto-energy. But this process makes sense only under one condition if crypto-energy (the amount of money) is returned from circulation with a high added volume. As a result, we should convert the expression (1) to the formula:

\section{$\mathrm{M}-\mathrm{C}-\mathrm{M}^{\prime}$,}

where $M^{\prime}=M+\Delta M$ is the initially advanced amount, increased by a certain money growth, called as surplus value.

Expression (2) describes the money circulation. The last act in a special role of a carrier of free crypto-energy (money capital). The entire sequence of the circulation of this substance is designed so that it is possible to extract in the exchange process of produced commodities and services (associated energy) for the money capital of some surplus value, which comes from the environment.

It follows, that the direct purpose of the capitalist is the appropriation of surplus value. The receipt of use value (quality assurance), declared by the ISO 9000 standards system, goes by the wayside in his understanding. At best, he will solve the problem of reducing

\footnotetext{
$\dagger$ Crypto- (combining form representing Greek kryptós and meaning "secret", "hidden") is a part of compound words indicating any hidden action or condition.
} 
production costs. The creator of Theory of Constraints, Eliyahu Goldratt, has a similar opinion [11-13]. The same judgments can be found in works of other authors [14-18].

Direct and immediate connection between use value (quality) and exchange value has a complex and ambiguous relationship in different conditions. That is why they try to use indirect characteristics, for example, costs, to quantify the quality of a product (service). It should be noted that this indirect approach on the stage of production or logistics (in the case of physical costs) is quite acceptable. Never the less this direct dependence is not confirmed with the transition (либо conversion) to a transaction costs.

From the foregoing, it follows that problems arising during the implementation of the QMS are directly related to the lack of direct unambiguous dependence between target destination of a commercial organization (profit and crypto-energy generation from the environment) with not a fully defined quality management task.

The available literature analysis $[2-8,19-22]$ on the improvement of the QMS issues leads us to understanding that:

- the task of providing the end consumer with the goods of the needed to him quality is not crucial for a commercial organization in a capitalist society;

- the application of methods available to society at the stage of the industrial development of production is not enough to the unconditionally problem solving of goods production (services provision) of the quality required by the end consumer, since it does not allow him to get an objective representation of the real quality of the goods (services) offered to him.

\section{Results and Discussion}

The main direction of the problem solution of improving the QMS at the present stage, in our opinion, should be focused on:

- the need to create equal information conditions for the manufacturer, large retailer and the end consumer;

- the reduction in transaction costs by disclosing their structure and content for the full range of stakeholders. Transaction costs should be as affordable and transparent as possible. Especially because the transition of the world economy in the active phase of the digitalisation makes this problem almost solvable.

The concepts of the Third Industrial Revolution, Industry 4.0 and other developments both at the state and at the corporate levels quickly began to incorporate into government programs and business strategies. Businessmen and departmental experts both in our country and abroad already fully felt the scale and the inevitability of change in their markets and in their areas of responsibility [19, 23-27].

In the broadest sense, the "digitalisation" process is usually understood as the socioeconomic transformation initiated by the massive introduction and assimilation of digital technologies for the creation, processing, exchange and transmission of information.

Digital economy is an activity in which the key factors of production are the data presented in the digital form, and their processing and use in large volumes, including directly at the time of their formation, can significantly increase efficiency, quality and productivity compared to traditional forms of management in various types of production, technologies, equipment, during storage, sale, delivery and consumption of goods and services [28-33].

The basis of digitalisation is digital platforms. This is inherently the quintessential toolkit of the digital economy. Integrating almost all the latest technologies digital platform gives its' users access to modern digital processing technologies and to a free competitive market, fundamentally changing the rules of the game in the corresponding segment. 
Currently, the main developers' attention is focused on the four technologies presented in table 1 .

Table 1. Description of the basic digitalisation technologies.

\begin{tabular}{|c|c|c|c|c|}
\hline $\begin{array}{c}\text { Technology } \\
\text { name }\end{array}$ & $\begin{array}{c}\text { Appearanc } \\
\text { e time }\end{array}$ & $\begin{array}{l}\text { Market } \\
\text { volume }\end{array}$ & Notes & The essence of technology \\
\hline $\begin{array}{c}\text { Cloud } \\
\text { computing }\end{array}$ & 2006 & \begin{tabular}{|c|} 
In 2009 \\
$\$ 17$ billion \\
(up to $5 \%$ \\
of the entire \\
IT market) \\
in $2014-$ \\
$\$ 175$ \\
billion. \\
Marketplac \\
e will be \\
worth \\
$\$ 206.2$ \\
billion in \\
2019 , and \\
will grow to \\
$\$ 278.3$ \\
billion in \\
$2021[34]$ \\
\end{tabular} & $\begin{array}{c}\text { Advantages in comparison with } \\
\text { classical IT architecture: } \\
\text { - saving on computing power; } \\
\text { - fault-tolerance ; } \\
\text { - high speed data processing; } \\
\text { - saving on licenses and } \\
\text { software; } \\
\text { - cheap server space; } \\
\text { - accessibility (limited only by } \\
\text { the lack of the Internet); } \\
\text { - sustainability to DDOS-attacks }\end{array}$ & $\begin{array}{c}\text { Computing resources are } \\
\text { available to Internet-user as } \\
\text { an online service in data } \\
\text { processing technologies. } \\
\text { Software as a service } \\
\text { (SaaS) remains the largest } \\
\text { segment of the cloud } \\
\text { market. } \\
\text { They made a significant } \\
\text { contribution to the } \\
\text { foundation of the } \\
\text { technological, economic } \\
\text { and conceptual } \\
\text { components of the digital } \\
\text { economy }\end{array}$ \\
\hline $\begin{array}{c}\text { Big Data and } \\
\text { business } \\
\text { analytics } \\
\text { (BDA) }\end{array}$ & $\mid \begin{array}{c}\text { active since } \\
2010\end{array}$ & \begin{tabular}{|c|} 
The big \\
data market \\
is expected \\
to be worth \\
of $\$ 189$ \\
billion by \\
the end of \\
2019. As \\
per \\
predictions, \\
the big data \\
market will \\
grow at a \\
rate of \\
around $23 \%$ \\
in the \\
period 2014 \\
to 2019 [35] \\
\end{tabular} & $\begin{array}{l}\text { A variety of methods and } \\
\text { integrated software products, } \\
\text { including those from IBM, } \\
\text { Oracle, Microsoft, Hewlett- } \\
\text { Packard, EMC, the Apache } \\
\text { Software Foundation } \\
\text { (HADOOP), etc. }\end{array}$ & $\begin{array}{c}\text { It is the instrument of } \\
\text { decision-making based on } \\
\text { large amount of } \\
\text { information, processes } \\
\text { structured and unstructured } \\
\text { data (including data from } \\
\text { disparate independent } \\
\text { sources), provides human } \\
\text { perceived results }\end{array}$ \\
\hline $\begin{array}{l}\text { Cognitive } \\
\text { technology }\end{array}$ & $\begin{array}{c}\text { active since } \\
1990 \mathrm{~s}\end{array}$ & $\mid \begin{array}{c}\text { By } 2019 \\
\text { about } \$ 31.3 \\
\text { billion }\end{array}$ & $\begin{array}{c}\text { Up to } 20 \% \text { of the global volume } \\
\text { of procurement is focused on } \\
\text { detecting fraud, eliminating } \\
\text { threats and making } \\
\text { recommendations. The second } \\
\text { place is trade (procuring the work } \\
\text { of agents of the automated } \\
\text { customer service) }\end{array}$ & $\begin{array}{l}\text { Technologies "work" with } \\
\text { our cognition: evaluate our } \\
\text { attention, monitor our } \\
\text { condition, monitor the } \\
\text { work of the brain, and try } \\
\text { to "understand" a man }\end{array}$ \\
\hline $\begin{array}{l}\text { The distributed } \\
\text { registry (blocks } \\
\text { transactions } \\
\text { chain / } \\
\text { Blockchain) }\end{array}$ & 2008 & \begin{tabular}{|c|} 
Worldwide \\
spending on \\
blockchain \\
solutions is \\
forecast to \\
be nearly \\
\end{tabular} & \begin{tabular}{|} 
The main advantage in \\
maintaining a distributed registry \\
using blockchain technology is \\
the exclusion from the system of \\
an intermediary employee who \\
processes or verifies information
\end{tabular} & \begin{tabular}{|c|} 
This is the construction of \\
distributed databases, each \\
record of which contains \\
information about the \\
history of ownership, \\
which makes it extremely \\
\end{tabular} \\
\hline
\end{tabular}




\begin{tabular}{|l|c|c|c|}
\hline & $\begin{array}{c}\text { \$2.9 billion } \\
\text { in } 2019 \text {, an } \\
\text { increase of } \\
88.7 \% \text { from } \\
\text { the } \$ 1.5 \\
\text { billion spent } \\
\text { in } 2018[35]\end{array}$ & difficult to falsify this \\
information
\end{tabular}

A preliminary analysis of the capabilities of the above-mentioned technologies, from the perspective of the possibility of providing all interested parties (либо stakeholders) with the full amount of information they need to make a decision, is showed the need to make the process of obtaining reliable information extremely transparent. Thus, to the greatest extent a distributed registry technology is applicable to solve such a problem.

Let's get acquainted with its capabilities and principles of work more detailed based on sources $[36,37]$.

So, the "distributed registry" technology (blocks transactions chain or blockchain) is based on the methodology for constructing distributed (decentralized) databases in which each of the available records contains complete information about the ownership history, making it extremely difficult information falsification.

The structure of the distributed registry is organized as follows:

- the registry (blockchain) is a continuous chain of data blocks, where each subsequent block is associated with the previous one using the set of records contained in it;

- at the same time, all the information in the chain is fully recorded in each block;

- new blocks are added to the very end of the chain, thereby extend the volume of the blockchain;

- all the blocks of the chain are located in strict chronological order, are connected by a cryptographic signature accompanying each change in the system. Each transaction is completed by writing information to the blockchain and bringing this information to all nodes of the network;

- chain node is a single computer. It stores the current version of the blockchain. The appearance of a new block on the network causes all nodes of their blockchain updating;

- internal operations in the network are processed and recorded without participation of a third-party service.

The blockchain technology is organised in such a way that transferring a private key by a user to a certain person at the same time means transferring to him all rights to own the values stored in a certain section of the blockchain. The possibility of registering confirms the authenticity of the person. As a result, the trust relationships are established between the parties, since no one will gain access to the information if he does not have the appropriate keys.

Blockchain is a single protected data registry presented in the form of electronic files. That's why one block may be copied and write off the information more than once. Different types of services can be built on this technology. In particular, it is possible to organize both private and public service.

Private blockchain is intended for the development of private business. It submits to the goals of the corporation, it is closed and centralized. The creators by themselves supported and controlled it.

Anyone can join public blockchains. The community itself administers them. Security in this case is ensured by a decentralized server affixing timestamps and providing peer-topeer network connections. In this case, blockchains are convenient to use for recording events, data operations, managing identification and authenticating the source.

At present, at least one and a half dozen of commercial projects based on blockchain technology have been practically implemented in various fields of economics and medicine. 
Table 2 . Information on the practical implementation of blockchain technology.

\begin{tabular}{|c|c|c|c|c|c|}
\hline Platform name & \begin{tabular}{|l|} 
Year of \\
foun- \\
dation
\end{tabular} & Location & $\begin{array}{c}\text { Total } \\
\text { financing }\end{array}$ & Website & Destination \\
\hline Provenance & 2014 & \begin{tabular}{|l|} 
London, \\
UK
\end{tabular} & $\begin{array}{c}\$ 1.1 \\
\text { millions }\end{array}$ & www.provenance.org & $\begin{array}{l}\text { It is designed to reinforce clients } \\
\text { trust to brands and retailers by } \\
\text { providing key information about } \\
\text { each product: materials, } \\
\text { ingredients, suppliers, } \\
\text { manufacturing processes, } \\
\text { equipment to be used, conditions } \\
\text { of storage and transportation and } \\
\text { etc. Each stage of the product's life } \\
\text { cycle is monitored and recorded on } \\
\text { a blockchain, following which this } \\
\text { information is verified and get an } \\
\text { open access. User can view the full } \\
\text { story of the product using the } \\
\text { Provenance application or he can } \\
\text { integrate the electronic receipts } \\
\text { into the company site or look } \\
\text { through the url and / or QR code } \\
\end{array}$ \\
\hline $\begin{array}{l}\text { ShipChain: the } \\
\text { end-to-end } \\
\text { logistics } \\
\text { platform on the } \\
\text { base of } \\
\text { Ethereum }\end{array}$ & 2017 & \begin{tabular}{|c|} 
Los \\
Angeles, \\
USA
\end{tabular} & $\begin{array}{l}\$ 30 \\
\text { million }\end{array}$ & www.shipchain.io & $\begin{array}{l}\text { It is oriented on the carriage of } \\
\text { goods. It allows you to track the } \\
\text { transportation of goods from the } \\
\text { moment of shipment from the } \\
\text { production to the final transfer to a } \\
\text { customer. It is a blockchain } \\
\text { member in Transport Alliance } \\
\text { (BiTA). It promotes the product } \\
\text { for general use by transport- } \\
\text { expedition companies. } \\
\text { It uses the immutability and the } \\
\text { decentralization of blokchain } \\
\text { technology and the IoT-devices. } \\
\text { To collect information about the } \\
\text { movement and conditions of cargo } \\
\text { transportation in real time, it } \\
\text { creates a "history" of the life cycle. } \\
\text { It allows user to automate the } \\
\text { logistics processes associated with } \\
\text { the exchange of data, document } \\
\text { management and financial } \\
\text { calculations }\end{array}$ \\
\hline $\begin{array}{l}\text { Waltonchain: } \\
\text { software for } \\
\text { IoT- } \\
\text { technologies }\end{array}$ & 2016 & $\begin{array}{c}\text { Shenzhen, } \\
\text { China }\end{array}$ & $\begin{array}{l}\$ 10 \\
\text { million }\end{array}$ & $\begin{array}{c}\text { www.waltonchain.or } \\
\mathrm{g}\end{array}$ & $\begin{array}{l}\text { One of the solutions for logistics } \\
\text { and enterprise-level supply chains } \\
\text { that integrate RFID data and IoT } \\
\text { into the blockchain. It is well } \\
\text { supported in China and other } \\
\text { countries and Southeast Asia } \\
\end{array}$ \\
\hline
\end{tabular}




\begin{tabular}{|c|c|c|c|c|c|}
\hline \begin{tabular}{|c|} 
TE-Food: \\
Food Tracking
\end{tabular} & 2015 & \begin{tabular}{|l|} 
Albstadt, \\
Germany
\end{tabular} & $\begin{array}{l}\$ 19 \\
\text { million }\end{array}$ & \begin{tabular}{|c|} 
www.tefoodint.com, \\
www.te-food.com
\end{tabular} & \begin{tabular}{|} 
It brings together producers, \\
distributors, retailers and \\
consumers of food products to \\
eliminate fraud in the food industry \\
and to reduce costs for companies \\
on logistics. It uses RFID tags to \\
track the time and place time and \\
place of food production, the \\
conditions for the raw materials \\
production for it, and the time of \\
delivery to the supermarket. All \\
information is recorded into the \\
blockchain and is provided to the \\
buyer through QR codes
\end{tabular} \\
\hline $\begin{array}{l}\text { MediLedger: } \\
\text { drug logistics }\end{array}$ & 2017 & \begin{tabular}{|c|} 
San \\
Francisco, \\
California \\
, USA
\end{tabular} & $\begin{array}{l}\$ 16 \\
\text { million }\end{array}$ & $\begin{array}{c}\text { www.mediledger.co } \\
\text { m }\end{array}$ & $\begin{array}{l}\text { It traces the origin of } \\
\text { pharmaceuticals according to the } \\
\text { rules of the Drug Supply Chain } \\
\text { Security Act (DSCSA). It is } \\
\text { focused on the storage of } \\
\text { synchronized public data } \\
\text { guaranteeing all network } \\
\text { participants: a common "source of } \\
\text { truth"; ensuring the confidentiality } \\
\text { of transaction data; using smart } \\
\text { contracts to enforce business rules } \\
\text { and complete transactions within } \\
\text { the system. } \\
\text { It maximally protects the personal } \\
\text { data of users, ensures that they will } \\
\text { not be published, broadcast, sold or } \\
\text { used without the knowledge and } \\
\text { consent of their source. The } \\
\text { information in the MediLedger } \\
\text { network is not available even to } \\
\text { the Chronicled manager if their } \\
\text { source doesn't want it }\end{array}$ \\
\hline
\end{tabular}

Source: own research.

Table 2 provides information on the practical implementation of blockchain technology in areas closed to solving the problem of improving the QMS. Their successful implementation confirms the possibility of using this technology to solve the problem of managing transaction costs, as well as informing all participants in the market exchange process. Therefore, the proposed methodology can be used in the formation of a system of informing the QMS end user about the current state of the quality of goods and services in the consumer market.

\section{Conclusions}

1. The task of providing the end consumer with the goods or services of the quality required by him is not a determining one for a commercial organization in a capitalist society.

2. The application of methods available to society at the stage of industrial development of production does not allow the end consumer to get an objective idea of real quality of the goods or services offered to him. 
3. The creation of equal information conditions for the manufacturer, large retailer and end user is the main direction of solving the problem of improving the QMS at the present stage. Transaction costs should be as affordable and transparent as possible.

4. The most acceptable option for solving the problem of disclosing the structure and content of transaction costs at the present stage of digitalisation is the technology of the public distributed registry (Blockchain), the implementation of which for solving related tasks has shown good results.

This paper was financially supported by the Ministry of Education and Science of the Russian Federation on the program to improve the competitiveness of Peter the Great St. Petersburg Polytechnic University (SPbPU) among the world's leading research and education centres in the 2016-2020.

\section{References}

1. M. Gelman, The Ministry of Energy provoked itself the "diversion" on the Druzhba pipeline (2019) URL: https://newizv.ru/article/general/11-052019/diversiyu-na-nefteprovode-druzhba-sprovotsirovalo-samo-minenergetiki

2. V. Lapidus, Dr. J. Juran, Criticizes ISO 9000 standards, Stand. and qual.,11, 71-75 (1999)

3. J. Seddon, ISO 9000 standarts: a disease of the economy? Bus. Exc., 4, 8-13 (2005)

4. J. Seddon, Quality that cannot be felt (2019) URL: http:/quality.eup.ru / MATERIAL Y10/quality_feeling.htm

5. V. Versan, ISO 9001 Standards: their role in the ISO 9000 standards of the version of 2008. Stand. and Qual., 7, 66-68 (2006)

6. V. Versan, ISO 9000 standards: patterns of development. Stand. and Qual., 1, 56 (2008)

7. L. Podobedova, E. Malyarenko, Rosneft laid on Transneft the costs of damage for the "dirty" oil (2019) URL: https://www.rbc.com/business/27/04/2019/ 5cc42af59a79473ed185e8f8

8. A. Trunina, Belarus lifted a ban on the export of petroleum products due to "dirty oil" (2019) URL: https://www.rbc.ru/economics/21/05/2019/ 5ce42ea89a7947be7c31a7c9

9. M.V. Zhulkov, The phenomenon of energy in the history of human thought. Philosoph. Thought, 6, 1-18 (2016)

10. V.E. Lepsky, The evolution of management ideas (methodological and philosophical analysis). Kogito-Centre, 107 (2015)

11. E.M. Goldratt, The Haystack Syndrome: Sifting Information Out of the Data Ocean. P. 262 (1991)

12. E.M. Goldratt, J. Cox, The Goal. A Process of Ongoing Improvement. P. 384 (2004)

13. W.H. Dettmer, Goldratt's Theory of Constraints: A Systems Approach to Continuous Improvement. P. 444 (2015)

14. T. Corbett, Throughput Accounting: TOC's Management Accounting System. P. 174 (1998) 
15. J. Cox, D. Jacob, S. Bergland, Velocity: Combining Lean, Six Sigma and the Theory of Constraints to Achieve Breakthrough Performance - A Business Novel. Free Press, p. 320 (215)

16. O. Cohen, J. Fedurko, Theory of constraints fundamentals. TOC Strat. Solut. Ltd., p. 332 (2012)

17. E.S. Reinert, How rich countries got rich... and why poor countries stay poor. P. 384 (2008)

18. H.-J. Chang, Bad Samaritans: The Myth of Free Trade and the Secret History of Capitalism. P. 288 (2009)

19. International standard ISO 9001. Quality management systems. Requirements (2015)

20. E.V. Levchenko, The impact of digitalization on the development of a quality management system. Bulletin of SGSEU, 4 (73), 9-14 (2018)

21. T.D. Maslova, O.G. Alekseeva, M.V. Chigir, S.G. Bozhuk, From admission to graduation: Problems and solutions in the sphere of the quality of training highly qualified personnel for business in the context of NBIC. Pp. 256-259 (2019) DOI: 10.1109 / PTES.2018.8604210.

22. A.R. Bril, O.V. Kalinina, O.A. Rasskazova, Financial and economic aspects of the assessment of innovative projects in the human resource management system. Pp. 5772-5782 (2018)

23. A.V. Keshelava, I.L. Khaet, Digital tools of the digital economy: basic questions and definitions. URL: http://digital-economy.ru/.

24. V. Mitin, Technologies of the digital economy: the pace and causes of growth. URL: https://www.itweek.ru/digitalization/article/detail.php?ID=207997

25. I.Z. Geliskhanov, T.N. Yudina, A.V. Babkin, Digital platforms in the economy: essence, models, development trends. Scie. and tech. stat. of SPbSPU. Ec. Scie., 11 (6), pp. 22-36 (2018)

26. G.I. Abdrakhmanova, K.O. Vishnevsky, G.L. Volkova, L.M. Gokhberg, Indicators of the digital economy. NRU HSE, p.268 (2018)

27. G.i. Abdrakhmanova, O.K. Vishnevsky, L.M. Gokhberg, Digital Economy, NRU HSE, p. 96 (2019)

28. Program "Digital Economy of the Russian Federation”. App. by ord. of the Gov. of the Russ. Fed.,No. 1632-r. (2017)

29. E.A. Gromova, Digital economy development with an emphasis on the automotive industry in Russia. 40 (6), p.4 (2019)

30. A.D. Borremans, I.M. Zaychenko, O.Yu. Iliashenko, Digital economy. IT strat. Of the comp. develop., 170 (2018) DOI: 10.1051/matecconf/201817001034.

31. D.S. Demidenko, V.V. Kulibanova, V.G. Maruta, Using the principles of "digital economy" in assessing the company capitalization. Pp. 6087-6091 (2018)

32. A.V. Bataev, Analysis and development the digital economy in the world. Pp. 61$71(2018)$

33. N. Alekseeva, N. Antoshkova, S. Pupentsova, Application of the Monte-Carlo simulation method in building and energy management systems. Adv. in intel. systems and computing, 983, pp.257-266 (2019) DOI: 10.1007/978-3-030-19868$8 \_26$. 
34. Gartner, Inc. Forecast: Public Cloud Services, Worldwide, pp. 2016-2022, 2Q18 Update (2019) URL: https://www.gartner.com/en/newsroom/press-releases/201809-12-gartner-forecasts-worldwide-public-cloud-revenue-to-grow-17-percent-in2019

35. International Data Corporation (IDC). (2019) URL: www.idc.com

36. N.D. Shurupov, Analysis of the possibility of using Blockchain technology in the procurement process. Design office of Gazprom Neft - Supply Ltd.

37. D.S. Demidenko, A.M. Malinin, A.N. Litvinenko, A new classification of the risks of the quality processes. Pp. 2892-2897 (2017) 